\title{
2
}

\section{INDIGENOUS RELIGION(S) - IN THE MAKING AND ON THE MOVE}

\section{Sámi activism from Alta to Standing Rock}

\author{
Siv Ellen Kraft
}

"We are protectors, not protesters", Mykay gently corrected Greg Johnson and myself during our first meeting. He and Greg were acquainted from Hawai ' $i$, his homeland and Greg's fieldwork area. Like thousands of others, mostly Native Americans, but including groups from large parts of the world, Mykay had come to stand with the Lakota against the 'Black Snake', the Dakota Access Pipeline. So had three Sámi women, it turned out, and a team from NRK-Sápmi. ${ }^{1}$ "This is indigenous people uniting", one of the Sámi women declared during their welcome ceremony that same day. It would have been hard to disagree. 'Global indigeneity' is key to the vocabularies of the INREL project, but it had so far existed on an abstract level of discourses and networks, at least for me. Here it seemed, very literally, to have come to life, conveyed by hundreds of indigenous flags and the consistent use of 'we' on banners, and in explicitly religious terms, manifested in the ceremonial infrastructure of the camps, the constant chanting, burning of sage and drumming, and the references on banners and sign-posts: "This is ceremony, act accordingly", "Water is Sacred, Water is Life". We were clearly on Lakota land, for a local cause, but one with potential for upscaling, along the lines of religious registers. ${ }^{2}$

I remember another impression from the day of our arrival: that of oddly familiar scenes, reminiscent of pictures I had seen from the Alta-conflict in Sápmi. Back home, I have since heard of similar associations. Journalist and former Alta-activist Anders Heger noted in the wake of a visit that walking through the messy mixture of "tipies, wigwams, pickups, camping wagons and small, modern tents", he would not even have to close his eyes "for the pictures to blend in with lávvus, ${ }^{3}$ the smell of reindeer skin and mountain grass, and a flaming northern light above the Finnmark tundra 36 years ago" (Heger, Klassekampen, 28.10.16, my translation). Former Sámi Parliament President Aili Keskitalo declared that Standing Rock "is our common cause. It has become 
symbolic, one may rightly say that this is the world's Alta-case" (NRK Nyheter 07.11.16, my translation).

I somehow discovered Alta at Standing Rock, based on a combination of distance and familiarity, and the mainly intuitive act of comparison through which they appeared. An attempt to follow up on these experiences and the questions they triggered, this chapter moves between Sápmi (the Sámi territories) and Dakota, and between the early and the current phase of international indigenous organisation and identity building, through a focus on Sámi activism at Alta (1979-81), at Standing Rock (2016-17), and back in Sápmi in the form of solidarity actions. I thereby hope to shed light on the emergence of indigeneity and indigenous religion(s) in Sámi contexts and on some of the dynamics involved. The timeline allows for a sense of developments across time and the work-in-progress nature of indigeneity and indigenous religion(s), in relation to consciousness raising, revival and refusal over this period. The geographical divide invites reflections on scales, encounters, and domains of usage and relevance. Based on this design and the overarching objective, the following questions have guided my work. First are articulations of indigeneity, religion and combinations of the two: the extent to which they are used (or not), where and in which contexts (or not at all), why (or why not) and with what results (if any). Second, and related to the generative dimension of protests: what is the role of encounters for processes of indigenisation and religion-making, and of the liminal spaces that frame and foster them?

I have proceeded along the lines of 'light comparison' (Gordon 2013), inspired by my mainly intuitive recognitions at Standing Rock and by the comparative logics of indigeneity and indigenous religion. My comparison is 'light' in the sense of focusing on a few cases, but with contextually rich descriptions, and a primarily inductive and explorative approach. I have worked with comparanda that were already connected, prior to my juxtaposition of them, and have followed connections, alongside making my own comparisons. While partial, limited and centred on a few of the thousands of people involved in the protests this design may, or so I hope, provide a window into the broader stories to which the cases belong, and some of the dynamics through which they have developed, including the role and logics of emic comparison. Indigeneity is a manifestly comparative phenomenon (Johnson and Kraft 2017: 3). "To be indigenous is to compare" (Johnson and Kraft 2017: 13), across scales and relative to context. It implies recognition of that which 'we' have in common, which makes us a 'we' and distinct from others (Johnson and Kraft 2018a).

A few words on my choice of cases: Alta is so far the largest Sámi protest and was followed by major changes in the relationship between the Sámi and the Norwegian state. The 'indigenous turn' started prior to Alta but was for the following decade framed by this particular protest. Standing Rock is an obvious choice right now, as the most global protest of recent times, one in which many Sámi were involved, and one that shares important features with the Alta-case. Both were large, non-violent, protracted, encampment-based, and anchored in 
the protection of particular rivers. Both staged media-events in the presence of massive police-forces, and both were talked about as points of no return, as historic and as destined to bring about radical change.

Methods and sources have been shaped by the timeline and geographies. I have visited the area of the camps in Alta and have talked to a number of the activists - many briefly, some more extensively. ${ }^{4}$ Standing Rock unfolded in my 'real time', and in a media-scape that has dramatically changed the premises of refusals ${ }^{5}$ and the potential for studying them. I visited Standing Rock in September 2016 and followed it from afar on a more or less daily basis to the forced closing of the camps in February 2017. ${ }^{6}$ Back in Tromsø, where I live and work, I have met with Standing Rock activists in diverse contexts and capacities, including solidarity events, public lectures (by myself and others), a public seminar at Sámi House in Oslo, student supervision, ${ }^{7}$ and more and less formal interviews.

I will start with contextual matters concerning Sápmi and the Sámi, and then move from Alta to Standing Rock, to Standing Rock in Sápmi, including a brief discussion of a recent protest; the Ellos Deatnu-movement in Finnmark county, inspired by both of these protests, and like both of them involving a river. Finally, I will briefly gather and compare key aspects pertaining to the protest-format and encounters, in regard to indigeneity and religion-making.

\section{Contextual matters}

Sápmi extends across four nation states, encompassing northern parts of Norway, Sweden, Finland and the Kola Peninsula of Russia. An estimated 80,000 to 100,000 Sámi live in this large area, the majority in Sápmi on the Norwegian side (around 50,000-65,000), which constitutes my main focus in this chapter.

Colonisation has been dated to the 16th century, by what was at that point the Danish-Norwegian and Swedish kingdoms (Sundström 2016: 212). Christianity was introduced during medieval times and gradually became the dominant religion from the late 17 th century, in the wake of systematic missionary projects, targeting ritual experts (noaidi, today often translated as shamans) and their drums particularly. From the 19th century, various assimilation projects were initiated, with the school system (including residential schools) as the main tool (Minde 2005). Sámi languages in many places disappeared almost completely, alongside a decrease in the number of self-identified Sámi, particularly in the coastal areas.

'Norwegianization' was dismantled as a political programme in the wake of World War II (Selle et al. 2015: 55) but was replaced by "passive Norwegianization" (Thuen 1980: 15), based partly on the institutionalisation of the welfare state system and partly on stigma connected to Sámi ways of life and being (ibid.: 54-60). The 1970s have become known as the 'Sámi spring', based on increased consciousness-raising and emergent resistance, much of which unfolded within the frames of the Alta-conflict. The dam was built, but the loss of the river was followed by a new phase of governmental relations between the Sámi and the 
Norwegian state (Bjerkli and Selle 2003: 21), involving major shifts, politically, institutionally and culturally. ${ }^{8}$

The early 1960s saw the first examples of an international orientation, ${ }^{9}$ but "the idea that the Sámi was an indigenous people, in the modern legal sense, was quite foreign to both the Nordic governments and to the great majority of Sámi until the Alta-case" (Minde 2003a:106, my translation) and became widespread only from the late 1970s (minde 2003a: 99). Fifteen Sámi delegates attended the founding conference of The World Council of Indigenous People (WCIP) in Port Alberni, British Colombia, in 1975. Among these were the artists Hans Ragnar Mathisen and Nils-Aslak Valkeapää, both of whom took part in its 'cultural programme' (Valkeapää as its first 'co-ordinator of culture') and both of whom contributed to expanding indigenous networks through this venue, through their art and personal travels, and through the organisation of festivals back home, in Sápmi. Valkeapää was the key figure behind the festival, Davvi Šuvva, in 1979, staged near Karesuando, in a Swedish and Norwegian border-area, as a week-long, camp-based event, and possibly the first ever (pan)-indigenous festival (Angell 2009). ${ }^{10}$ Davvi Šuvva gathered an estimated 3000 people from the broader Sámi region, along with Native Americans, First Nations, Inuit, South American groups, and representatives of the Kurds, and has been referred to as a catalyst for "a wider community of Sámi to begin to consider themselves part of a global indigenous community" (Angell 2009: 7).

I have asked some of the frontline activists about indigenous influences prior to the Alta-conflict. Jorunn Eikjok, from Vadsø, met Native American activists during a world youth festival in East Berlin in 1973, some of whom had recently fought at Wounded Knee (interview with Jorunn Eikjok, Oslo, 23.11.2018). In 1977 she attended a WCIP conference in Kiruna, and in 1979 she witnessed the introduction of Home Rule in Kalaallit Nunaat, amid rising tensions over the fate of the Alta-Kautokeino river. It convinced her that change is possible and further sparked her anger over conditions in Sápmi: "To me the Altadevelopment was a continuation of the awful colonial history that had lasted 400 years. I experienced what was happening in Alta as a knife to the throat concerning the existence of the Sámi as a people" (Eikjok 2019: 1-2; my translation).

Today a scholar of law and a famous artist and activist, Ánde Somby was another young Sámi at the frontline of the protests. Asked (by me) about indigenous influences prior to the conflict, his first mention was the American Indian Movement as an inspiration for $\mathscr{C} S V$, a concept born during a meeting in Sirma in 1972, and related to Sámi who were politically and culturally radical, and confrontational towards Norwegian society (see Guttormsen 2000). In the wake of the Wounded Knee Massacre (also in 1972), journalists asked whether the Sámi had anything corresponding to the Native American warriors. The answer was CSV: Sámi force, "peaceful with teeth" (interview with Ánde Somby, Tromsø, 31.08.18, my translation), referred to by some newspapers as 'Lapp power'. An example of early lines of influence, this story also indicates a new direction of comparative logics, born out of the international indigenous movement and the 
recently established and still new category of 'indigenous people', and spread through encounters, newsmedia coverage and protest literature. The protesters were inspired by the Gandhi campaigns during the 1930s and Martin Luther King Jr.'s civil rights movement during the 1950s and '60s (Parmann 1980: 173), and by books like Vine Deloria's Custer Died for Your Sins (1969) about Red Power in the USA and Dee Brown's Bury My Heart at Wounded Knee (1970) (Minde 2005: 17).

\section{Ellos Johka - La elva leve - let the river live}

The Alta-case involved government plans to dam the Alta-Kautokeino river for hydroelectric power, based on a claimed need to modernise the region. Sámi organisations succeeded in stopping a first proposal (in 1968) which would have put the Sámi village Mazi under water. Nationwide protests began with revised plans of 1978, and involved an estimated 20,000 Sámi and Norwegians and a wide range of protest-forms, including civil disobedience. Between 5000 and 10,000 visited one of two camps established near the construction site (Detsika and Stilla).

The protesters comprised a coalition of more or less independent groups, with The People's Action against Development of the Alta-Kautokeino river as

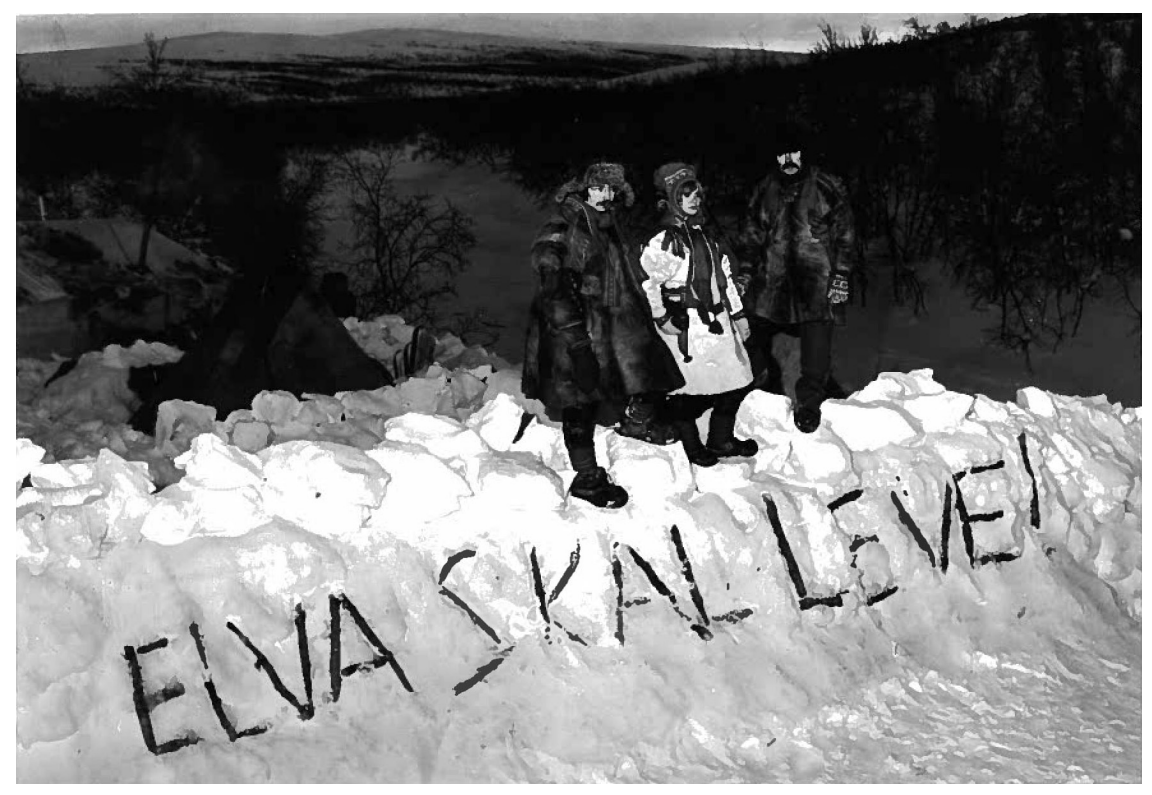

FIGURE 2.1 The main slogan of the Alta-movement 'La elva leve (let the river live)' written in snow. From the left, Åge Gaup, Marry A. Somby and Josef Halse.

Source: Niillas A. Somby, used with the permission of Ánde Somby. 
the most embracive and in charge of the camps (Heitmann 1984: 115). Having started as a Sámi case in Mazi, the shift to Alta (an ethnically mixed and more Norwegianised area) opened up the case in different directions. Alta remained a Sámi case, related to the protection of reindeer grazing land and calving in the area, but became an indigenous case, related to international legislation. It was from the start an environmentalist case, concerned with saving one of the most untouched areas of European wilderness, and for many locals it was about salmon-fishing primarily, in what was also one of Europe's richest salmon-rivers. The conflict is retrospectively described as one of the most extensive, bitter and dramatic in Norwegian history. ${ }^{11}$ Finnmark county was split in two over the issue, and in complicated ways, crossing ethnic and party lines, friends and families.

Sources of local tension included a large influx of sympathisers from the broader region, the rest of Norway, and to some extent from abroad, bringing ways of thinking and acting that to many locals were new and (negatively) associated with hippies and radicals (Heitmann 1984). Environmentalism was among the dubious imports, and civil disobedience was regularly framed as attacks on democracy (Parmann 1980: 186). The Sámi dimension was, as such, a source of tension. Some of the non-Sámi locals were less than happy with supporting what was also a Sámi issue, and some Sámi were intimidated by the focus on Sámi-ness.

The camps were dominated by Norwegians, while many of the key actions were dominated by Sámi and aimed for national and international audiences. Media coverage was extensive and ranged from local media focus on the river and fishing primarily, to a focus on the Sámi and to some extent on the indigenous angle in national media (Bjerkli and Selle 2003: 21). The international dimension supported the Sámi more exclusively, by way of support-declarations and media interest. Both the indigenous movement and Sami activists used the opportunity to shame the Norwegian government, by referencing a lack of ability to live up to standards that they supported outside of Norway (Hjorthol 2006: 82).

Detsika was a combination of political think tank, cultural workshop and training camp, comprised of protesters from the south (approx. 37 percent), ${ }^{12}$ the overall region (approx. 45 percent) and foreign visitors (approx. 18 percent). A local Alta-varing recalls a strong sense of "protest-enthusiasm" (No. aksjonsglede) among the activists, many of whom were students and environmentalists (telephone-interview 24.05.18). Friends of mine from Kautokeino and Tromsø remember a festival-like event, exciting encounters, concerts with famous artists like the Cree-musician Buffy Saint-Marie, and set late in an unusually warm summer. A 'Detsika Songbook' resonates with the Northern Norwegian ballad tradition. Yoik was a staple from the start, at the camps and as a part of direct actions. A yoik-song won the Melodi Grand Prix Norway in 1980, at that time an annual media-event of nation-wide proportions. Titled Sámiid Adnan (Sámi earth/ground) and dedicated to the protesters, its lyrics refer to yoik as "more 
powerful than explosives". ${ }^{13}$ Minutes from camp-meetings feature respect for Sámi traditional knowledge and lectures on such knowledge (Mikkelsen 1971, 1980: 97; Hjorthol 2006: 39).

Detsika was dominated by (non-Sámi) Norwegians, but the fact that they were allies, and mostly not local, may have contributed to safe-zones for new and old articulations of Sámi-ness. Contrasting a position of near invisibility in Alta, the protests placed Sámi-ness first, and as a positive resource. Asked to comment on Sámi-Norwegian relations at the camps, compared to everyday life in Alta, a local Alta-varing reasoned along these lines (telephone-interview 24.05.18). Norwegians from the south came with little knowledge of the Sámi, often combined with romantic stereotypes. Mostly clueless of the subtle rules governing SámiNorwegian relationships, they would ask questions not normally asked either due to established patterns of silence or because the matter would be obvious and taken for granted. As an example, she used Sámi practices of not emptying warm coffee grounds, explained with reference to this being harmful to nature. Her point was not that Sámis cynically deceived their gullible visitors from the south, merely that they engaged dynamically with the resources at hand, and chose positive solutions when possible, in this case by way of adding an environmental dimension to everyday practices (telephone-interview 24.05.18).

The choice of Oslo for key direct actions contributed to national and international upscaling, while securing proximity to news-channels and politicians. First among such actions was an occupy-event and hunger strike from 8th to 15th October 1979 by Sámi Action Group, a small group of young activists, most of them from Finnmark and some of them with experience from indigenous activism in Greenland, Canada and Alaska. ${ }^{14}$ The hunger strike was inspired by a group of Kurds whom Niillas Somby had met at the Davvi Šuvva festival earlier that summer. His brother Ánde was initially sceptical and voted against the hunger strike strategy during a meeting in Oslo, as did the majority of the Sámi gathered. Trust in the Norwegian government was not at its best, Ánde recalls. He feared that they simply would not care: "If you're going to stage dive, then you need to know that people will catch you" (interview with Ánde Somby, Tromsø, 31.08.18). Jorunn Eikjok recalls a brief Action Group talk in the wake of the meeting, in which they decided to go ahead with the plans. And she remembers feeling calm and completely convinced, based on her activist background, by built up anger, and a spiritual experience (No. andelig opplevelse). During a carride with Niillas a great, strong light appeared to her, convincing her that this would work out (interview with Jorunn Eikjok, Oslo, 23.11.2018). "You will see me on TV 3 or 4 days from now", she told her parents as they left Tana for the $1820 \mathrm{~km}$ drive to Oslo. On approaching Oslo at 5 in the morning she felt confident and safe, thinking to herself of people in the capital that "here you are sleeping. In 2 days you will all know of the Sámi, and it's going to change Norway" (interview with Jorunn Eikjok, Oslo, 23.11.2018, my translation).

Jorunn was fine, it turned out, and people in Oslo did care. Both Jorunn and Ánde describe the response as overwhelming. People were sympathetic to their 
cause and eager to learn about this case and the Sámi more generally: "It was almost as if you could hear people's brains 'sparkle"” (No. knitre) (Interview with Jorunn Eikjok, Oslo, 23.11.18). What they witnessed - live and on TV - was a lávvu, a Sámi flag, yoik, Sámi dressed in gákti (traditional clothing) and banners: "We are hunger-striking", "Let the river live"; all of this in front of the Norwegian Parliament, the centre of state politics (Figures 2.2 and 2.3). The hunger strikers stayed for a week, for a performance that differed sharply from established patterns of interaction. Unlike many indigenous peoples elsewhere, the Sámi lack a warrior tradition. ${ }^{15}$ Myths and legends tell of smart manoeuvres and the ability to hide and disappear on the tundra. Colonial stories tell of shame, silence, and secrecy, of avoiding confrontations and hiding practices and symbols associated with Sámi-ness (Eidheim 1987). The hunger strike was neither silent nor submissive. This was an in your face-form of action, non-violent but with teeth, as in a combination of $\check{C} S V$, Gandhian ideas, and Native American strategies.

Adding to dramatic actions was an extensive information-flow at the site, through posters, flyers, speeches and stands. Jorunn was in charge of the daily reading of telegrams for the people gathered: "At first they came from Norway, then from the Nordic countries, and then they started coming from across the whole world; so this made indigenous people around the world conscious of this" (interview with Jorunn Eikjok, Oslo, 23.11.2018, my translation). Meanwhile,

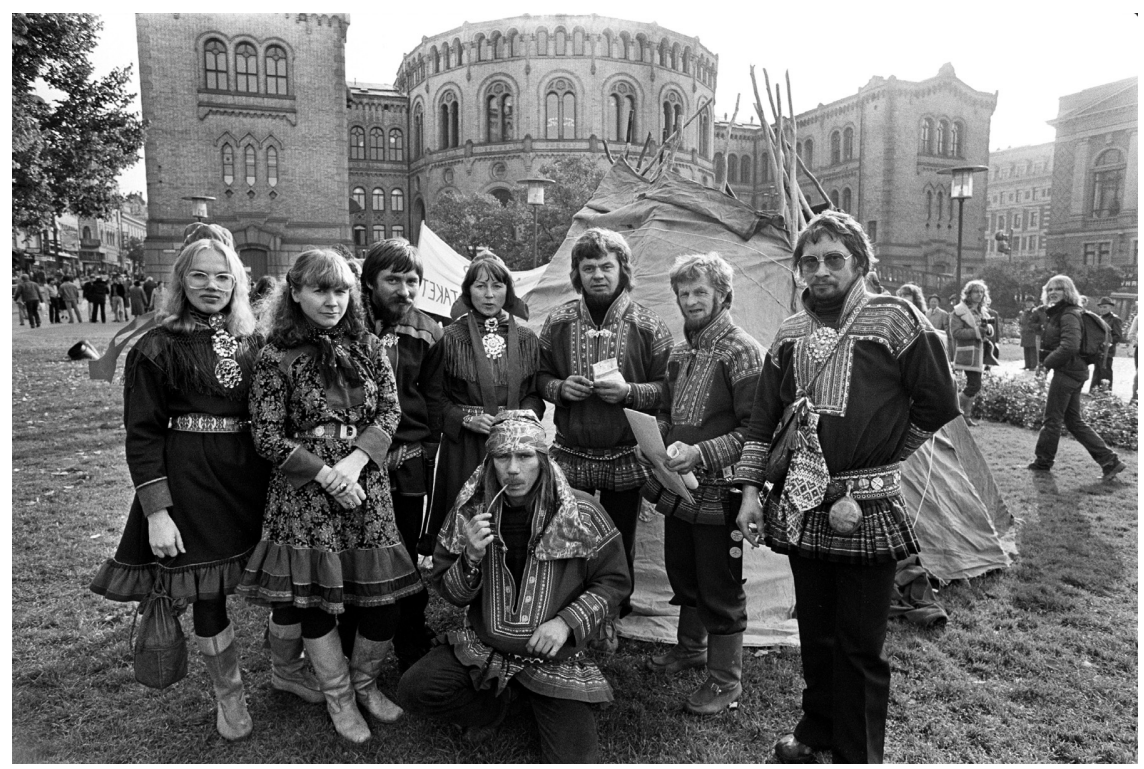

FIGURE 2.2 Sámi Action Group and supporters in front of the Norwegian Parliament, October 8th, 1979.

Source: Bernt Eide/Samfoto/NTB scanpix. 


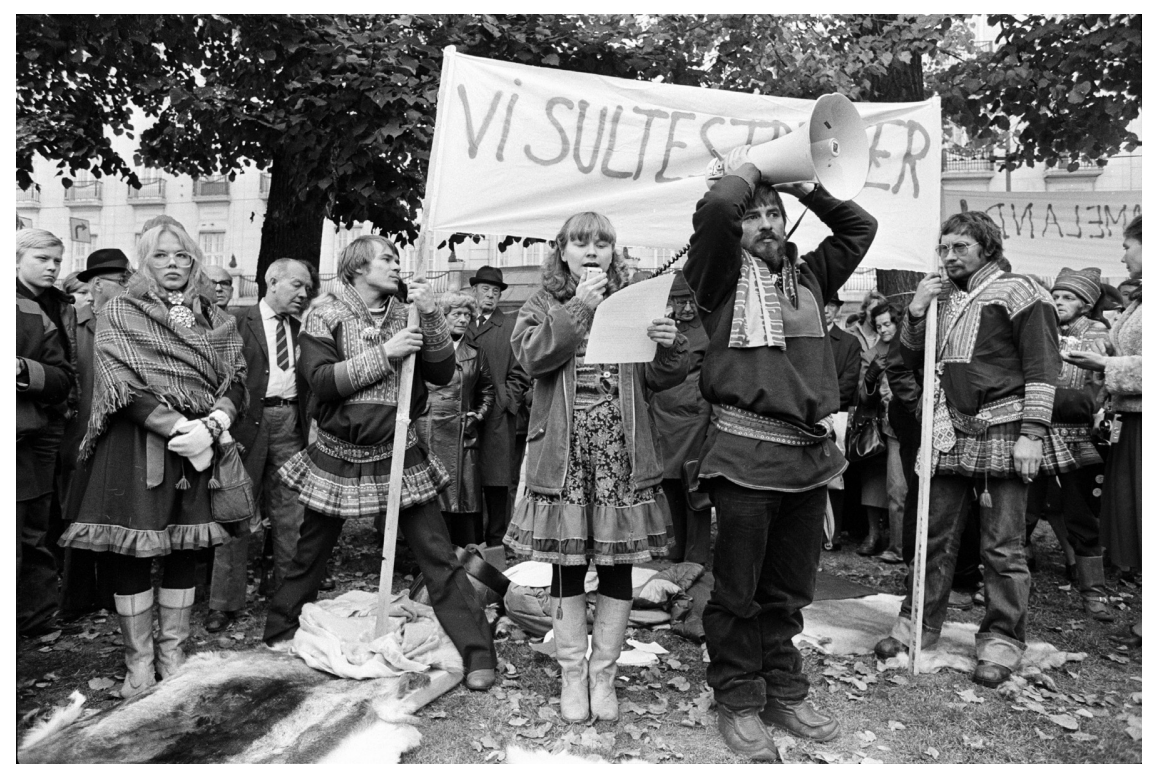

FIGURE 2.3 Jorunn Eikjok reads telegrams. Left: Synnøve Persen and Ánte Gaup. Right: Mikkel Gaup. Holding the microphone: Niillas Somby.

Source: Bernt Eide/Samfoto/NTB scanpix.

some 100,000 copies of the recently launched journal Charta 79 (Figure 2.4). Tidsskrift for Urfolksspørsmål (Journal of Indigenous Issues) were sold on the streets of Oslo, much to the surprise of the Action Group members responsible for it (interview with Ánde Somby, Tromsø 23.11.2018). The journal offered articles about the Alta-conflict, alongside information on indigenous struggles around the world, and including a 'Solemn declaration' issued at the first meeting of the World Council of Indigenous People, in 1975, in the name of what was at this point a new 'we'.

Back in Sápmi, the most dramatic event was the clearance of the Stilla camp on 14th January 1981, with some 600 police officers (one tenth of the Norwegian police force at the time) shipped from the south to remove around 1000 frostbitten activists, chained to each other and to the construction site. Many Sámi and Norwegians will at some point have seen images from this event. NRK featured the slogan "We were here first" written in the snow in front of a snow-barricade. At the frontline were Sámi activists dressed in gákti, holding Sámi flags, and yoiking. Behind them chains were cut and activists were carried away, one by one (Hjorthol 2006). It was a dark and cold day, Ánde Somby later noted (1999). Newspapers talked of D-day. Locals in Alta remember a war-like situation, with hundreds of policemen marching. Older people were reminded of World War II. The colonial imaginary is striking retrospectively. 


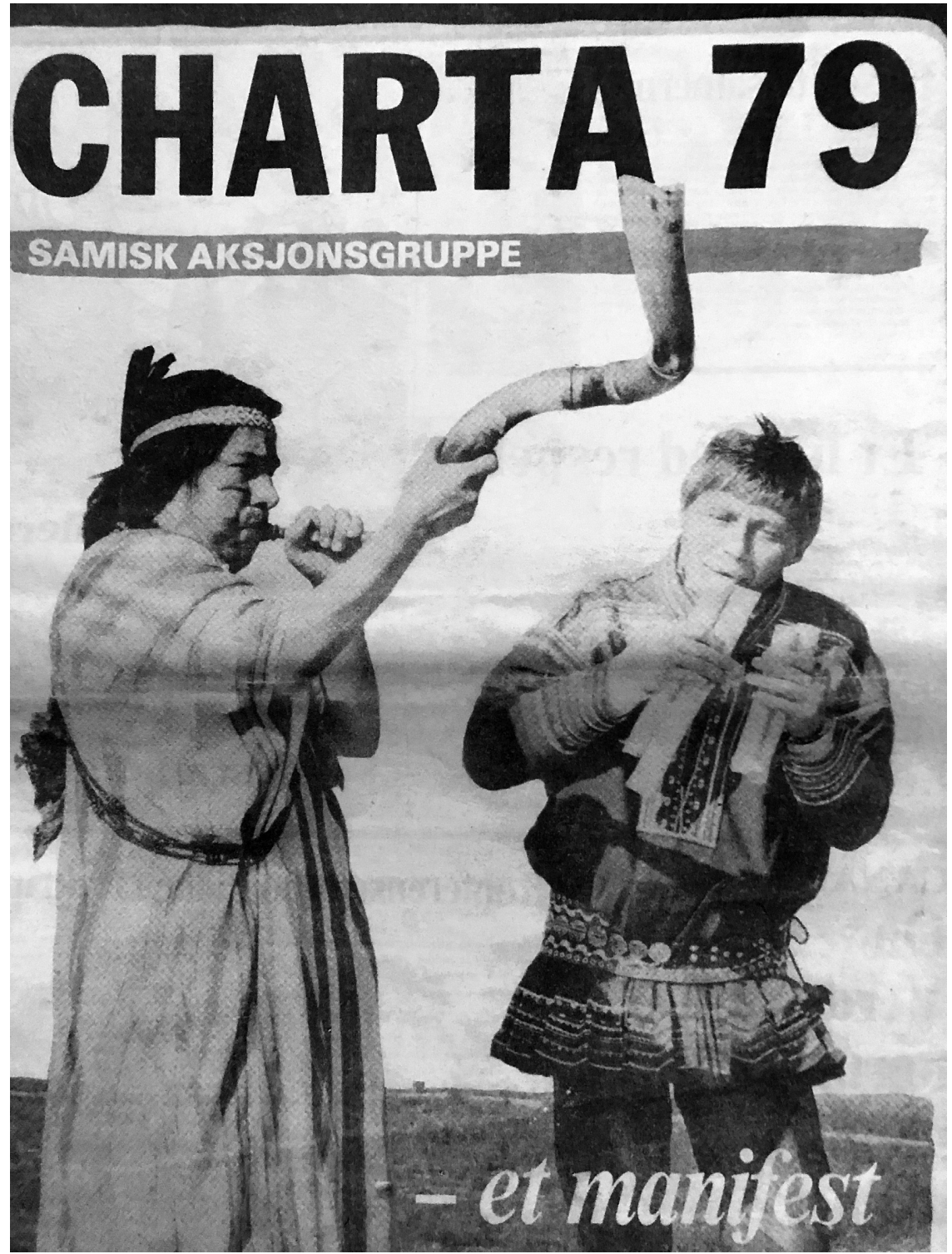

FIGURE 2.4 Front page of Charta 79, featuring Nils-Aslak Valkeapää at the Davvi Šuvva festival, 1979.

During a public seminar at Sámi House in Oslo, November 2018, three of the key Alta-activists talked about their experiences, in a conversation led by Ánde Somby (seminar, Sámi house in Oslo, 23.11.2018). Jorunn Eikjok spoke of confidence gained in indigenous contact zones; of transitional moments during encounters in Oslo; and of thrills, inspiration and spiritual confirmation. Rávdná 
Anti, one of the camp-leaders at Detsika, focused on learning to speak up, on solidarity and community building, on life-long connections, and on events that have stayed with her and still - 39 years later - made her voice break and her eyes teary. On arriving at the first day of the hunger strike, she said, "I saw Jorunn, Synnøve, Niillas. And I was so happy. The place swarmed with people. And I thought 'damn (No.faen), we are winning this case'. It was the greatest pleasure of my life, seeing them there" (seminar, Oslo, 23.11.2018, my translation). Ragnhild Nystad, then head of the Sámi Union in Oslo, described a dramatic period and emotional turmoil; her fear for the lives of the hunger strikers; the thrill of victories along the way, including support from local Norwegians; and the birth of a life-long commitment to be Sámi, openly and with pride. "We lost the case", she ended:

The dam was built. But we also won. . . Norwegian public opinion discovered us, and then politicians followed. And what we won most of all - all those Sámi who sow gákti now, and who are more Sámi than me (laughs), and demand the right to be Sámi. We won with the Sámi awakening.

(seminar, Oslo, Ragnhild Nystad 23.11.2018, my translation)

The audience included peers of the panel and members of a younger generation of Sámi activists, including the Standing Rock activists Sara Marielle Gaup Beaska and her husband Beaska Niillas, seated in the front row.

\section{Religion - at home and away, deterrents and incentives}

Asked to comment on religion during the protests, Jorunn described spiritual experiences as common in her family and among the Sámi more generally, but limited to Sámi contexts: "It has been denied, and we haven't dared to show it in Norwegian settings . . .; probably some kind of collective traumatising in the wake of missionising, that have stuck for generations" (interview with Jorunn Eikjok, Oslo 23.11.18, my translation). Indigenous contexts were different, at least for her. Jorunn recalls from the WCIP conference in Kiruna in 1977 that:

We were inspired to be Sámi. It was wonderful to be valued as we were, . . . and to be a part of this community, and of ceremonies that indigenous peoples from North America had, and which we were completely in tune with. . . They didn't have to explain to us, we simply understood. . . And it inspired, you know, the spirituality (No. spiritualiteten) that we carried. As I explained to you, this . . has been denied, and we haven't dared to display it in Norwegian contexts.

(interview with Jorunn Eikjok, Oslo 23.11.18, my translation)

A scrap-book entrance written in the context of her encounter with Wounded Knee activists in 1973 reflects such inspiration and the understandings it inspired, 
along with emergent notions of environmental destruction as connected and encompassing:

The land is our mother, and from her comes life: life that is food we eat, water we drink, the earth we walk on, and the beauty we see. To give this life, the land must be respected and cared for. If it is exploited to greed and dollars it will die.

(written in English, cited in Minde 2000: 36)

Back in Sápmi in 1978, Jorunn worked for a while at the ethnographic department of Tromsø Museum. While there, she used the Museum's resources to explore international developments and Sámi history. Her research did not include the (pre-Christian) Sámi religion, she told me. Related to her solid grounding in local spiritual traditions perhaps, Jorunn did not see the need for studies of the ancient past, at least not then and there, faced with a political conflict.

Yet, some Sámi were interested. Dikka Storm, conservator at Tromsø Museum, remembers an increasing interest in (pre-Christian) Sámi religion and mythology during the Alta-conflict, so much so that they put together a list of suggested readings (interview with Dikka Storm, Tromsø 11.09.18, my translation). ${ }^{16}$ Among the visitors were young Sámi artists like Nils-Aslak Valkeapää and Hans Ragnar Mathisen (interview with Dikka Storm, Tromsø 11.09.18, my translation), both of whom from this period used elements from Sámi religion in their art and in indigenous contact zones. Early examples of such usage include the previously mentioned 'Solemn Declaration', issued in the wake of the WCIP conference in Port Alberni, 1975. Addressed to 'all nations' on behalf of a collective 'we', the declaration juxtaposes mythological elements from different indigenous traditions, including the Sámi concept of 'sons of the sun' (Keviselie 1986). As WCIP's first cultural co-ordinator, Valkeapää must have been involved in the writing of the declaration. A decade later, The Sun, My Father (Beaivi, áhčažan, 1988), for which he received the Nordic Council Literature Prize in 1988, helped reclaim and revitalise the 'sons of the sun' for Sámi audiences.

The re-claiming of Sámi (pre-Christian) religion may have started in contact zones like the WCIP in Port Alberni, in what was at this point a new assembly, in search of a united front. Home grounds came with other contexts, incentives and encounters. I have found no sacred claims among the slogans, banners, programmes, buttons, songs and meeting minutes stored in the Alta-case archives, or in media coverage from the period. Nor have I found drums or other references to the pre-Christian Sámi religion, or the emergent registers of indigenous religion(s), articulated at the WCIP conference in Alberni a few years earlier. None of the activists whom I have spoken to recall anything along religious lines, and some of them speak of the lack of spirituality as a weakness of the movement. There were examples of Christian solidarity sermons and of supportive statements on the part of priests and bishops, but mainly from the south. 
A group of Sámi women who occupied the Prime Minister's office turned to the Pope for support, rather than to the State Church in their own country. ${ }^{17}$ Hunger strikes mimic sacrificial rituals, in this case reflecting the existential scope of the threat as "a knife to the throat of Sámi culture" (in Jorunn's phrasing), but they were not talked about in religious registers. Back-stage spiritual experiences (like Jorunn's light vision) remained private.

At least three elements can shed light on the absence of religious registers. First is the predominantly national context of the Alta-conflict, involving Sámi against the Norwegian state. Yoik and gákti were already established markers of Sámi-ness and were thus available options for framing the protest. Second is the lack of established religious symbols of Sámi-ness, due partly to existing practices of hiding religion in inter-ethnic contexts and partly due to the position of Christianity as the dominant religion among both Sámi and Norwegians, and thus lacking distinguishing potential. Third is the highly secular orientation of Norwegian politics, with little room and allowance for religious claims. In summary, there was little to gain from using religious registers and it was risky to do so.

Let me add a final story. Niillas Somby was one of the founders of the Sámi Action Group and one of the hunger strikers in 1979. In the wake of a Supreme Court decision in favour of the plant, he was found guilty of a failed attempt to blow up a bridge and placed in custody on charges of fire placement, with a penalty time-frame of 21 years. After time spent in jail and in hospital (he lost one arm and an eye in the explosion), he managed to escape to Canada. His brother Ánde recalls an intricate plan, involving an after-dark escape, a change of cars and dying his hair along the way, high heels to fit the description in a 'borrowed' passport, gloves to cover the lost arm, and a first-class ticket to Vancouver. In Vancouver he was received by members of a First Nation people that Ánde had met during a yoik-tour earlier that year. Niillas ended up staying three years there, before being caught and brought back home (interview with Ánde Somby, Tromsø 31.08.2018).

At an art-seminar in Tromsø on 27th January 2017, Niillas told the story of the failed explosion, his injuries, and his time on the run. He described it as the best years of his life and as a time of learning and remembering. From 'the Indians' (No. indianerne), he received his spiritual education (No. andelige utdanning). He realised that spirituality was what was lacking during the Alta-case and what was needed for the Sámi to survive. "Politicians dare not speak about rights to our own spirituality", he claimed. The Christians - although often equipped with a conscience - misdirected it:

It is the earth that is our shrine (No.; helligdom) . . Indigenous spirituality means to take care of each other, of animals, of everything that exists . . . the colonists used Christianity to colonise us. We must use our own spirituality to decolonise the system 
His choice of terminology resonates with an established distinction between 'Sámi spirituality' and 'Sámi (or indigenous) religion' (sometimes also referred to as pre-Christian Sámi religion or indigenous religion). The latter refers to the past. The former speaks to the here and now, and its anchorage in ancestral traditions.

After the seminar we talked about his stay in Canada, and I asked him to elaborate on his understanding of spirituality. He told me about an incident during his childhood that convinced him of the spiritual powers of his grandfather, and he spoke of other truths passed on to him. What he learnt in Canada resonated with these partly forgotten memories, as truths he once knew and therefore could recognise. Similar truths were articulated in the speech "To the Norwegian State Government Court”, during his trial on 27th April 1985. Niillas stated that he did not expect to be treated fairly, since this legal system differs from that of his people's traditions. He referenced the brothers and sisters who had for tens of thousands of years lived on this land and utilised spiritual registers that he had encountered during his stay among First Nations as well as an environmental paradigm that had emerged at the time of Alta, but was not used to frame this protest:

We have not left any wounds on the earth our mother. You are about to lead the earth to destruction. The earth is not only our mother. You are ripping the hair of mother when you are cleaning the woods of trees. You are sucking up mother's flesh when you are digging your cruel mines. Your hunger for land seems to be endless. . . . Your passage through time and history is not long. Even so, you have managed to convince us all that if you get to move on unhampered, you will kill all life, including yourself.

(Johansen and Kjeldsen 2005, my translation) ${ }^{18}$

\section{From Alta to Standing Rock}

Standing Rock engaged a new generation of Sámi activists, born in the wake of the Alta-protests, four decades of institution building on the part of the indigenous movement, and the establishment of indigeneity and indigenous religion (Clifford 2013: 15; Niezen 2012: 131). Their indigenous world is more established and accessible than that of their predecessors, through digital media and an expanded number of contact zones and networks. NRK Sápmi circulates indigenous news on a daily basis, and most Sámi have access to a continuous flow of Internet-based information and options for connectivity.

Standing Rock is one of many protests that have circulated through Sámi channels, but by far the most attended to, ${ }^{19}$ for several reasons. First is the proximity to this particular part of the world, through a combination of linguistic access (most Sámi speak English), established Sámi diaspora societies in the USA, and exposure to Native Americans through popular culture. Second is the availability of media-technological facilities and competences among organisers 
and the Sámi. The water protectors facilitated global communication, through the establishment of an efficient and elaborate mediascape; social networking sites like Facebook and Twitter; content sites like YouTube and Flickr; and professional newsfeeds offering short films, edited videos, blogs, and 'breaking news' reporting live from the action. ${ }^{20}$ The Sámi are to a large extent on these sites and platforms, and could thus follow them in real time and participate from afar. ${ }^{21}$

Third is the global framing. ${ }^{22}$ Asked why he decided to travel to Standing Rock, one of the Sámi protectors told me during our conversation that it is "the most global indigenous protest ever". He simply had to be there, to support and to learn. Sámi President Keskitalo's reference to Standing Rock as 'the world's Alta-case' points in similar directions, as do my, and Greg's, first impressions (Figure 2.5).

Keskitalo's formulation captures the upscaling involved from Alta to Standing Rock. I was initially struck by similarities between their key slogans: Water is life (among 'Water Protectors' at Standing Rock) and Let the river live (among 'River Savers' in Alta). Both refer to specific rivers and use a language of protection, but their translational potential differs, along with different potential for upscaling and different links to religious registers. Let the river live refers literally to a particular river, of interest primarily to locals. Water is life refers to a river and water in general, and thus to the foundations of life, to all people, everywhere. Notions of environmentalism reinforced their respective potential for upscaling. The Alta-case took place in the wake of a paradigm shift, from one in which environmental issues were seen primarily as local concerns to current notions of interconnections and co-dependencies (Hironaka 2014: 24), ${ }^{23}$ but it was dealt with in the former primarily. Alta was not about Mother Earth. It was

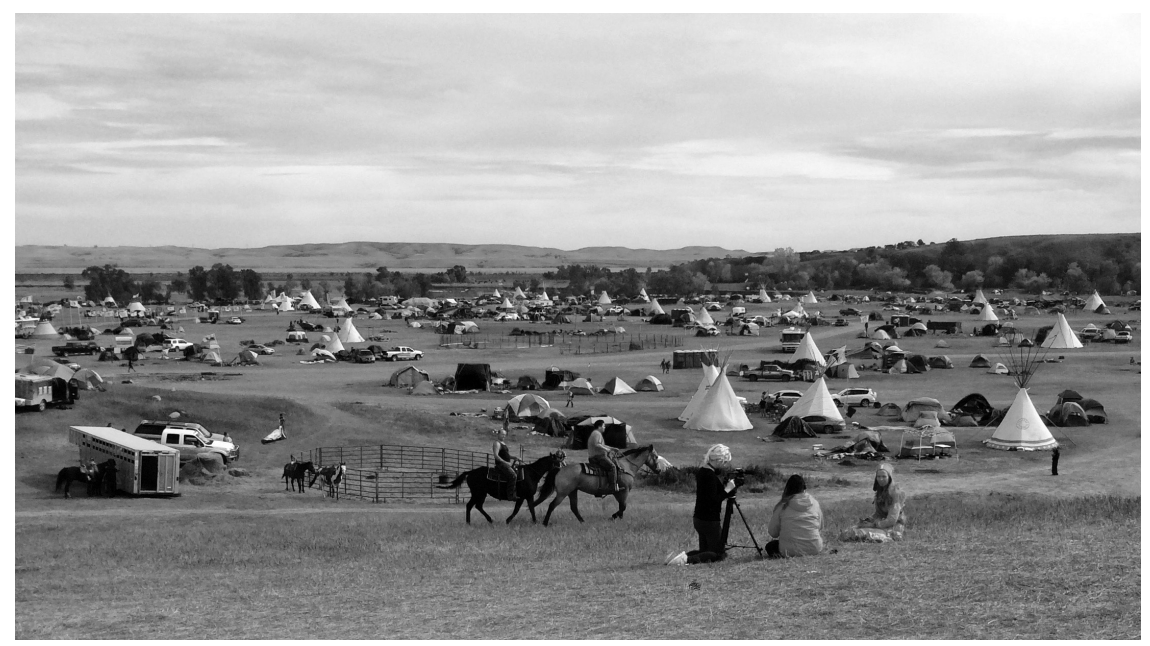

FIGURE 2.5 Oceti Sakowin camp.

Source: Greg Johnson. 
talked about in the local registers of fishing culture, outdoor-life (No. friluftsliv), and reindeer-husbandry primarily. Indigenous people were allies but were not included among the victims of this particular case. The scales were predominantly those of the local-national, not that of the local-global axis of Standing Rock.

The ritual system of Native Americans is superior to ours, Ánde noted in one of our conversations about Standing Rock and the Alta-conflict. He was referring to public settings and what has traditionally been a lack of space for collective ritual performance among the Sámi. In contrast, Standing Rock could draw upon precedence from pan-Indian traditions, like with the Ghost Dance and Peyote religion from the 1880s, and a political context with allowance for religious registers. Novel to Standing Rock was the consistent use of a global frame, articulated through religious registers. Religion was the main language of camp rituals and direct action performances, on the ground and online, and expressed through a selection of key terms: water is sacred, water is life, Mother Earth, prayer and ceremony. ${ }^{24}$ Prayer and ceremony were, at least by the autumn of 2016, established as key forms, enforced by all the leading groups at the camps, and a more or less obligatory part of performances and representations. They were articulated as rituals in the narrow sense of the term (chanting, water ceremonies, sweat-lodges etc.), and in the wide sense of the term (to frame specific actions or even camp-life as such). Action guidelines asked people to 'go in ceremony', 'act in ceremony', and 'be in ceremony', in order words, to take on a persona of perpetual sanctity. 'The sacred' spoke to this same effect. To articulate something as sacred is to make a claim for its position as inviolable and to frame opposition as sacrilege. Claims are claims, and accordingly open to contestation, but in this case were supported by discourses on environmentalism and continued colonialism, and in the presence of worldwide audiences, based on a mediascape that the protectors created, controlled and made skillful use of. Numerous YouTube videos feature tanks against prayer, uniforms against regalia, weapons against flowers, marching against dancing. As Ghandian-style dramas, these performances demonstrated a moral high ground to the activists themselves and their audiences, and as part of a history of abuse, now with Mother Earth among the victims of continued colonialism. As sacred claims, they performed the absoluteness of demands. As scripted performances they helped channel and amplify emotions, and thus to support the non-violent strategy of elders and organisers.

\section{Sámi at Standing Rock}

The Main Circle constituted the nerve centre of the camps. The central sacred fire was situated here, along with a sound system; an information board; and tables for people to eat, socialise, listen to music, and take part in various midscale ceremonial activity. Welcome ceremonies were the most clearly structured of the rituals taking place during our stay. Newcomers would start by anchoring 
their indigeneity in a specific home ground, often through a sentence in their native language. Next, they addressed the Lakota and the Sioux tribe leadership, expressed gratefulness for being welcomed and declarations of solidarity with the cause. Then a performance was offered, through established vocabularies of indigeneity on the level of words (Mother Earth, Water is Life etc.) and on the level of aesthetic forms (e.g. drums, dancing, chanting, storytelling, traditional clothing). The 'we' was consistently articulated as kinship (uncles and aunties, sisters and brothers) and was extended in time and space (to ancestors, homelands and Mother Earth). Finally, there was a clear division between elders ${ }^{25}$ (those holding particular authority) and everybody else, among whom informality was expected, through sharing and co-operation - in short, through building a community.

On 30th September, 2016, three Sámi women were welcomed at this site: Sofia Jannok (from Sápmi on the Swedish side), Sara Marielle Gaup Beaska ${ }^{26}$ (from Sápmi on the Norwegian side), and her sister Inger Biret Gaup, the first two of whom are famous musicians. Introduced by an enthusiastic Master of Ceremony as "our indigenous sisters from the Arctic", the Sámi entered the circle in their gákti for a 30-minute performance, shaped by a protocol that they clearly knew and understood. Having first thanked the hosts, expressed support for the case and offered greetings from their people, Jannok invited Dave Archambault, the then Chairman of Standing Rock Sioux Tribe, to sit on a reindeer-skin from Sápmi. Seated on this iconic item of north-Sámi material culture he was offered a selection of gifts, collectively expressive of the cause (a bottle of water from the Arctic) and their identity (a reindeer-hide pouch, a sewing bag and a wooden cup). "We are one", Jannok concluded the gift-giving, then down-scaling to the level of Sámi identity, "We hear you, we see you. . . . The fight you have is the fight we have". The gifts were followed by Sara Marielle's "We Speak Earth" yoik (Gulahallat Eatnamiin), which she performed to the beat of Sámi (shaman) drums, in this context described as the heartbeat of Mother Earth.

Pictures from the welcome ceremony were shared widely online, along with short films from direct action the following day. They feature the Sámi dressed in gákti, with their fists held high, and banners stating that "Water is Sacred" and "Sámi Stand with Standing Rock". Some ten months later, I came across a filmed version of the entire ceremony, posted to the 1473 members of the Facebook group "North American Sámi Searvi". An example of shifting scales and of the intricate circuits of contemporary indigeneity, we have in this case a cyberspace diaspora, witnessing performances anchored in their distant homelands, on stages closer to their diaspora-setting, yet belonging to a different indigenous community. In the words of one of the group members: "It brought tears. Giitu (Sámi for 'thank you') for all who helped bring this gift to those who could not be there at the time". ${ }^{27}$ Back in Sápmi, Sámis had real-time access to these same stages, through these same media.

Having been welcomed at the camp, the Sámi articulated their traditions through established protocol: a Sámi flag by their lávvu, reindeer skin for 
sleeping, and gákti. Unlike the more casual dressing of most of the activists outside of ceremonies, the Sámi dressed traditionally at all times. Their knowledge of traditional dress also proved useful in other ways. A YouTube video from the local casino, a few miles from the camp area, shows their return in December 2016, together with a Native American friend from the September camp. Posted on Jannok's (public) Facebook page under the headline "Sápmi back at Standing Rock", the video introduces an expanded group of Sámi visitors: Sara Marielle and her husband Beaska Niillas, their two children and grandmother, along with Inger Biret Gaup and five other Sámi, including one of my master students and her boyfriend. "This is not cold to us", Sara Marielle responded to a comment on the weather. As northern Sámi they are used to the cold and competent in dressing for it, and this was a competence they wanted to share. Having noted during their first visit the loss of traditional Lakota knowledge in regard to winter clothing, due to the colonial context and the forced end of buffalo-hunting, they hoped to help reclaim indigenous competences in new forms, by way of Sámi traditional knowledge and based on imported reindeer hide from nearby areas in First Nation Canada. ${ }^{28}$

A mixture of highly practical and highly symbolic exchanges was, at least for this Sámi group, characteristic of the Standing Rock experience. Winter clothing belonged to the former, as did the timing of the visit; Beaska Niillas later told me that they wanted to add hope at a time of increased challenges at the camps. One particular prophecy was an example of the latter. Prophecies have in the Native American context been a key form of symbolic exchanges. At Standing Rock a particular prophecy dominated, connected to the identification of the pipeline with 'the Black Snake'. Jannok refers briefly to the Black Snake in a documentary about her life and career, ${ }^{29}$ and Sara Marielle and her sister both refer to it in a NRK Sápmi interview prior to their visit (Pulk and Rasmus 2016). A 30-minute radio interview with Inger Biret Gaup offers a more elaborate version:

The reason why all these tribes have come to Standing Rock now is a prophecy by spiritual leaders in many of these tribes seven generations ago. . . Those who saw this, saw that in seven generations there will be a case that will gather people around the world in a joint fight against a black snake. They obviously did not know what a pipeline was, so they said what they saw; a black snake. And they also saw that all the four colours of the medicine wheel would be gathered and support this case. And the four colours are red, which represents themselves, that is native Indians, and then yellow, which is the Asian indigenous peoples, and then black, the African indigenous peoples, and then there is white. And for a long time, they thought that was the white man, but right away when they saw us, and saw that we are actually white; we are - as far as I know - the only indigenous people that is white. They said "then that explains it, you are the white in the circle". So, they had in a sense been waiting for us, and that is why they want us to return, since it can only be solved when all the 
colours are gathered. The prophecy says that one will then manage to stop the snake.

(my translation from Norwegian $)^{30}$

Prophesies invite sense-making and sign-searching, as plots waiting for players to be identified and contexts to be translated. In the heat of the conflict, they added hope and promise, yet depending on the ability of the good side to rise, unite, and stick to the path laid out for them. What was until recently a local prophecy was in this context upscaled to the level of global indigeneity and threats to Mother Earth, and in ways that allowed for the maintenance of distinctions, in this case articulated as colours.

The Sámi has thus come full circle, compared to early encounters with the indigenous movement. During the first meeting of the WCIP (in 1975) their white-ness was a matter of concern. A famous story tells of attempts to convince sceptics by way of speeches and arguments, followed by a spontaneous yoik by Nils-Aslak Valkeapää which immediately settled the case and closed the argument (Valkeapää 1983; Minde 2003b: 85). At Standing Rock, and in the frames of prophecy, the Sámi were not only recognisably indigenous, but needed for the circle of indigeneity to be complete.

There were other Sámi visits over the course of the period and with different examples of scalar translations. I learnt of one of them, the 'World Drum Project', during the autumn of 2018. ${ }^{31}$ Born from a vision by a Sámi shaman (Kyrre Franck) and brought to life by a Sámi drum-maker (Birger Mikkelsen), the World Drum left Sápmi in 2006 and has since then been on the move, around the world, for an environmental mission intended to go on indefinitely, or as long as needed. More than 800 locations had been visited when I met its key organiser (Morten Wolf Storeide) in October 2016, along planned and unplanned routes, including diplomatic negotiations in the wake of an attached feather and a subsequent arrest by the United States Department of Homeland Security, on charges of crossing an international border with restricted objects. During the autumn of 2016, Kyrre and Morten Wolf Storeide set up a visit to Standing Rock. A blog post shares the following description of the drum's experiences at the camp:

Throughout the Water Ceremony, water songs were shared and the World Drum was played. Additionally, the refrain "Water is Life", "Mni Wiconi" was called out in many different languages and chanted by everyone in that language. A gentleman who had been at the fire circle the evening before announced that the Drum had been around the world 10 times. Many hands played the Drum that morning as the sun rose over Standing Rock, reflected in the water.

(Linda Daniels www.theworlddrumproject.com)

The World Drum travels light, with little luggage in the form of background information, including the contested position of the shaman movement that gave birth to her. What the Sámi shamans regard as a revival of their ancestral 
traditions are in the Sámi core areas (in Finnmark) often regarded as new and neo, and accordingly fake and false. On her own, the World Drum could blend in with established registers, on par with the drums of the Sámi musicians. What remained was the drum as a marker of Sámi-ness and indigeneity, anchored in Sámi traditions from the Arctic, recognisable according to the vocabularies of indigenous religion(s).

\section{Standing Rock in Sápmi}

Solidarity events were organised across Sápmi and in a variety of forms, ranging from concerts, to marches, rituals and sit-ins, and often involving both Sámi representatives and environmental organisations. I attended one of the first to take place in Tromsø, co-hosted by the Shaman Association and the environmentalist organisation Nature and Youth, ${ }^{32}$ a first time for these organisations to join hands according to their respective leaders. It was located on a beach and included a water ceremony designed for the occasion, performed by one female and one male Sámi shaman. The entire session was filmed and uploaded as a YouTube video statement of solidarity with Standing Rock. ${ }^{33}$

Adding to solidarity events were various support actions, from 'knitting for Standing Rock' (organised by a shaman), to statements by the Sámi Parliament and Sámi Church Council, extensive information-spread through Facebook and Instagram, and work on bank investments. A small group of Sámi activists was vital to a disclosure of Dakota Access Pipeline (DAPL) investments among Norwegian banks, which resulted in the withdrawal from the project by some of them, including The Norwegian Bank (DNB), and with repercussions beyond Norway, through similar actions directed to other banks, particularly in the USA. NRK Sápmi followed this from the start and was in 2017 awarded the journalist prize of Finnmark county for their work on DNB's involvement in DAPL (Larsson 2017).

Visits by Standing Rock allies constitute a third category of links and connectivity. Several allies attended events in Sápmi during and in the wake of the protest. The (Sámi) festival Riddu Riđđu organised a Standing Rock seminar with the Lakota activist HolyElk Lafferty among the participants (in 2017). The prestigious Nobel Peace Prize Award (in Oslo) gathered several Standing Rock leaders for a session on indigenous peoples in 2016, ${ }^{34}$ and various seminars discussed Standing Rock related issues. Many of them were covered by national and local media, and travelled extensively online.

Sara Marielle's "We Speak Earth" preceeded Standing Rock ${ }^{35}$ but was granted new meanings in this setting, as a combination of the Standing Rock anthem and the protest song for Mother Earth. I heard it live on three profiled public occasions: at Standing Rock, at the opening ceremony of Tråante 2017, ${ }^{36}$ and at my university's 50th anniversary celebration (in 2018). A YouTube version features Sara Marielle performing the yoik, along with a description of what it means to 'speak earth'. There is also a Facebook page devoted to the project, set up for 
"people wanting to help build pressure towards the politicians negotiating our future, due to climate change and global warming", and allowing for the posting of ideas and films of oneself performing the yoik (NRK, Verstad and Novikova 2017). Inger Biret Gaup offered examples of more explicitly religious articulations: "Every time anyone yoiks this yoik, the power of the resistance at Standing Rock increases! So don't be shy, learn the song, sing it again and again. You will release enormous powers, powers necessary to stop the atrocities against the Indians in North Dakota". ${ }^{37}$

Norwegian newsmedia helped circulate Standing Rock-registers and consistently abstained from critical comments. Religio-political mixtures are usually targeted in Norwegian newsmedia (see Døving and Kraft 2013). This came with versions of 'ceremony' and 'prayer' that make little sense from the perspective of Christian notions of 'religion' with which journalists are most familiar. Alternatively, the combination of a seemingly harmless religious vocabulary, an honourable cause (environmentalism), and a vulnerable agent (indigenous people) may have exempted the case from criticism.

\section{Ellos Deatnu - let the Tana River live}

At least one new movement can be linked to Standing Rock (and Alta); the Ellos Deatnu-movement, concerning fishing rights in the Tana River in Finnmark and involving Sámi on both sides of the border between Norway and Finland. During the spring of 2017 activists set up a camp on a small, uninhabited island and announced a moratorium, in effect a refusal as theorised by the Mohawk anthropologist Audra Simpson (2014). Newly installed fishing regulations are invalid, the moratorium declared, since they were enforced against the will of local communities, without consultation. ${ }^{38}$ The crew has worked actively to foster support and networks, through Facebook and social media, local meetings, festivals and concerts. ${ }^{39}$ An online moratorium office ${ }^{40}$ has been set up as an "advisory service for self-determination", and assistance in establishing moratoria.

Leading figures of the protest, Áslat Holmberg and Beaska Niillas, visited Standing Rock in December 2016. ${ }^{41}$ Beaska has, in media interviews, spoken of important support from Black Snake activists, including help with spreading news (NRK, Larsen 2017a), and has (like Keskitalo) referred to Standing Rock as "the World's Alta case" (Dagsavisen 9.12.2016). Among the videos posted on their Facebook site are several examples of Standing Rock references, through logos on clothes and posters focusing on related issues ${ }^{42}$ and through the juxtaposition of slogans, like with the closing reference of a YouTube presentation to "Ellos Deatnu, Mni Wiconi, ČSV", linking these movements in their local terms. ${ }^{43}$ Other juxtapositions have come from outside. One Facebook link features the Sámi musician Mari Boine with a new and expanded version of the Alta-slogan: "Ellos Sápmi, Ellos Deatnu" (Let Sápmi live, let Deatnu live, my translation from Sámi). ${ }^{44}$ Similar play on the slogan appeared during the prime-time TV-show Stjernekamp in 2018 (Ultimate Entertainer), featuring the Tana woman Ella 
Marie Hætta Isaksen, and Sámi members of the audience holding banners with the inscription "La Ella Marie leve" (let Ella Marie live, my translation from Norwegian). Since the autumn of 2018, the organisers have used "Ellos Deatnu" interchangeably with the upscaled (and Mni Wiconi-like) "Ellos Eallin" (long live life, my translation from Sámi).

Ellos Deatnu shares the indigenous and de-colonial frames of Standing Rock. Religion is no longer absent (like at Alta), but low key compared to Standing Rock, as with the "Water is life"-related "Let life live". Implicit references to a "sacred fire" is another example. Beaska Niillas speaks in videos of extinguishing the fire before closing the camp for the season, thus echoing the more violent closing of the camps at Standing Rock, and the use of camp-fires for ceremonial openings and closures. Fire was used for heating, light and cooking at Detsika four decades earlier, but I have not heard of symbolic usage, or the keeping of a particular fire burning. References to 'spirits' is a third example. In a video statement connected to the 'the last fire' and the closing of the camp, Beaska thanks "The Island, all the people and the spirits helping us" (@ellosdeatnu, 25th August 2017). ${ }^{45}$

While there is mostly subtle usage of religious registers there is more explicit and elaborate usage on the part of indigenous visitors, inserted on local Facebook pages and thereby religionising them from outside, as with a visit by Cree Nation activists in September 2018, posted on Ellos Deatnu's homepage and featuring in several of my Facebook connections including organisations like Greenpeace and Idle No More Sápmi, the personal pages of many of my Sámi Facebook-friends, and Native American protest sites.

\section{Concluding comments}

I initially understood 'the world's Alta-case' in the sense of the 'indigenous people uniting; this was like Alta only bigger. Back home, and in the contexts of Alta-activists and their stories, the taken for grantedness of Keskitalo's reference emerged as key. No longer 'white Indians' (see endnote 7), suspect in regard to claims for indigeneity (as at WCIP 1975), or new and unsettled in this role (as at Alta), the 'world's Alta-case' implies the taken for granted position of the Sámi as indigenous. Temporal and geographical scaling meets grand comparison in this case. Distant selves are compared to the Sámi, with Alta as the standard by which to measure Standing Rock and the current state of global indigeneity.

Looking back (in June 2019), both movements' ability to centre and focalise seems key: Alta united the Sámi, Standing Rock helped unite indigenous peoples. Camps came with facilities for home-making and community building, alongside incentives for the sharing and comparing of knowledge and practices. The sewing lessons of Sámi activists emerged from altertness to needs on the grounds and attention to what they could do and contribute. The identification of the Sámi as the missing colour in the medicine wheel speaks to sense-making in extraordinary contexts, conducive of the liminal or liminoid (Turner 1974), 
and it speaks to expanding horizons of the thinkable, the possible and the doable. Jorunn's conviction that "Norway will change" echo activist claims for the world at Standing Rock, including the ubiquitous sense of history making that Greg and I experienced while there, on the ground.

Although still modest compared to Native American standards, the indigenous turn among the Sámi has expanded the domain of religion, and in at least three ways. Articulations of local spiritual traditions is one. Jorunn felt encouraged to talk in these terms during encounters with Native Americans, at a time when Sámi spirituality was limited to private contexts and associated with shame. Niillas reclaimed his grandfather's spirituality in the company of First Nations. Indigenous encounters came with safe-spaces and incentives for doing so, outside the established restrictions of life back home and in the context of a new and supportive 'we'.

Second is the reclaiming of what is currently known as Sámi religion, Sámi shamanism or Sámi indigenous religion, often with space for the inclusion of the (local) spiritual traditions referred to previously. Artists were encouraged to search for mythological equivalences to the indigenous traditions they encountered during the 1970s, and to display and perform such traditions. Since then, a Sámi shaman movement has appeared, alongside a heritage version of Sámi shamanism (Kraft 2016), corresponding and comparable to similar developments among other indigenous peoples, in the wake of similar processes of reclaiming and revitalisation.

Third is the increasing circulation of indigenous religion. There was not yet a standardised vocabulary of indigenous religion at the time of Alta. There was one at Standing Rock. The result of such standardisation is not same-ness and flattening, at least for the material I have presented. Rather, this language of nativeness (to use a term suggested by Clifford 2013) is among Sámis used in up-scaled encounters primarily, and in performative settings first and foremost. We are dealing, moreover, with at least three different scales. ${ }^{46}$ One involves the local-global/micro-macro. One involves the public-private spectrum, and one involves validation - from the potentially primitivistic associations of local religious traditions to the positive associations of indigenous religion.

That said, 'returns' from outside may leave lasting traces. Indigenous religion exists above the level of (vernacular) first order concepts, as a second order abstraction, used to interpret and organise local terms, as for example with translations from the Sámi goddess Máttaráhkká to Mother Earth. Although still recognisably Sámi, Máttaráhkká becomes something more and different through this process, and such surplus is likely to stick to current understandings and usage.

What I have described is not a linear development from secularity (at the time of Alta) to religion (at the time of Standing Rock), but the emergence of a discourse, alongside examples of how it is used; then and there, here and now. Activist usage has been more common outside of than in Sápmi. Here and now, Sámi activism is still primarily secular. Yet, there have been sacred claims on protest stages in recent years, in response to increasing threats to the Sámi core 
areas, and in two forms, both of which can be related to indigenous religion. One concerns a political turn of Sámi shamanism; the other involves a religious turn among some of the reindeer-herders. An ongoing case in Hattfjelldal, in the South Sámi area, involves shamans, local reindeer herders, Friends of the Earth Norway and Sámi Parliament representatives, united in the defence of a sacred mountain against a planned power plant. In January 2019, Arctic Shaman Circle organised a welcome ceremony at a climate festival in Oslo, in conjunction with its launching as Europe's capital of environmentalism this year. Two months later, a Maori member of Arctic Shaman Circle attended the General Assembly of the United Nations, for a session on indigenous peoples and climate change, and for group meetings dedicated to a Rights of Mother Earth project. Like for the World Drum at Standing Rock, Sámi shamans are in these contexts able and allowed to act in the name of indigenous religion. Established in this position, they can offer ritual competences that have so far been lacking among Sámi activists, but that activists have encountered elsewhere, in indigenous worlds outside Sápmi. Back in Finnmark, Sámi reindeer herders have during the spring of 2019 used sacred claims to fight windmill-plans, ${ }^{47}$ and for an ongoing conflict in Kvalfjord municipality it has been suggested that a fjord should be granted consultation rights. ${ }^{48}$ Local traditions are basic to these claims, but within the frames of indigenous religion.

Neither completely fixed nor completely open, indigenous religion(s) has shifted and evolved over the time-span of this chapter. Most noticeable is a shift in environmental paradigms and a related potential for the up-scaling of cases and causes. The Solemn Declaration of WCIP 1975 speaks of land-grabbing and of subsequent destruction of indigenous life-ways, but not of threats to the whole world. The potential for up-scaling is key to contemporary indigenous protests. It is in the Sámi case linked to an increasing intertwinement of discourses on sovereignty and sustainability, and to new and positive concepts of indigenous peoples as protectors of Mother Earth.

\section{Notes}

1 NRK is an acronym for Norwegian Broadcasting. NRK Sápmi is a Sámi run division of NRK.

2 Thanks to the following scholars for reading drafts and/or sharing knowledge on issues discussed in this chapter: Jorunn Eikjok, Ánde Somby, Nils Oskal, Beaska Niillas, Dikka Storm, Marit Anne Hauan, Tuula Sharma Vassvik, members of the INREL-team and the INREL-research group in Tromsø, and members of the research group "Narrating the Postcolonial North: Travel, Writing, Performance" (Alta).

3 Sámi tents.

4 My sources for the Alta-case also involve newsmedia coverage, and the archives of Folkeaksjonen mot utbygging av Alta-Kautokeino vassdraget (The People's Action against Development of the Alta-Kautokeino river) at Alta Museum. As for previous research, there is an extensive body on the aftermath of the Alta-case, but surprisingly little - and for the most part by journalists rather than by scholars - focusing on the protests and the activists. For academic contributions see Jensen (2015), Minde (1982), Somby (1999), and Solbakk (2010). 
5 On the role of social media and cyberspace for indigenous protest-movements, see Hanna et al. 2016. On "refusals", see Simpson (2014). For a recent study of performances during indigenous activism, see Huarcaya (2015).

6 Greg Johnson and I have collaborated closely for this case, including joint fieldwork at Standing Rock (together in late September/early October; Johnson again in midNovember) and the creation of a news- and social media material archive. Joint publications on the Standing Rock protest include Johnson and Kraft (2017, 2018a, 2018b).

7 One of my master-students spent a month at Standing Rock and completed a thesis based on her stay at the camps and interviews with people that were there, in November 2019, see Vassvik (2019).

8 Among these were a Sámi Rights Committee and a Sámi Culture Committee in October 1980, the opening of the Sámi Parliament in 1989, a Sámi paragraph in the Norwegian constitution in 1988, and the signing of ILO-Convention 169 in 1990, in the wake of active participation of Sámi delegates in the process leading up to the establishment of the Convention (Bjerkli and Selle 2003: 22).

9 One example is an editorial article titled "The Sámi are the Indians of Sweden" in Samefolket (The Sámi People) (Minde 2003a: 106).

10 Davvi Šuvva means "Northern winds" in Sámi. It was followed by "Indigenous Days '84" in Tromsø, organised by Mathisen (Keviselie, not dated), the Nanna-festival (during the 1980s) and Riddu Riddu (from the 1990s).

11 See, http://meahcci.info/altakraft-n.htm; for another example, see Nilsen (2019).

12 These percentages were made by the camp-organisers. Most of the "foreign visitors" appear to have been from Sweden and Finland, along with enviro-activists from elsewhere in Europe. Press release dated 23.07.1979, Alta Archives.

13 Yoik had remained a live tradition, but used mainly in private settings (Graff 2016; Eidheim 1987). It was, from the 1960s, gradually removed from a category of heathen noise to the genre of folk music (Larsen 2009: 52), and during the Alta-protest moved from local, to national and even international stages.

14 What has become known as the occupation of then Prime Minister Gro Harlem Brundtland's office by 13 Sámi women (in 1981) belongs to the same series of images that were later to become emblematic. The backdrop was a new and longer-lasting hunger strike, involving near relatives of some of the women, who feared for their lives. After declaring that they would not leave until construction work halted, the women were removed by the police after 18 hours (Manndal 2011).

15 In the words of Nils-Aslak Valkeapäa: "Our culture knows of no phenomenon such as 'war' . . does not even recognize 'war' as a possibility" (1983), 1971:1).

16 Professor Ørnulv Vorren lectured on such issues at Tromsø Museum from at least the mid-1970s, for small groups of (mostly Sámi) students (Dikka Storm 11.09.18).

17 There is a letter to Pope John Paul II in the archives in Alta, dated 10th February 1981, signed Ellen Marie Gaup, Samisk kvinnegruppe (Sámi women's group). Written in the context of a second hunger strike, the letter ends with a plea for the pope to intervene. Alta Museum privatarkiv nr.1, serie P, arkivstykke 49.

18 My translation from a collection of speeches printed in Johansen and Kjeldsen 2005. The speech is also printed (and accessed here) from a database established by the same scholars, connected to the book: http://virksommeord.uib.no/taler.

19 The protest started in April 2016, with one tipi and a small group of local protesters. By the end of the summer between 5000 and 7000 people had joined the camps, by November as many as 10,000 .

20 On indigenous media networks, see Alia (2010).

21 Stand with-performances by indigenous groups (including Sámi) emerged into a social media ritual system of its own: often a banner stating that this particular group "stands with Standing Rock", along with traditional costumes and performances, usually in the form of dance, drumming or singing.

22 The closure of the case in Alta was followed by institution building along political and legal lines, centred on the Sámi Parliament and the U.N. There were few protests 
between the mid-1980s and the first part of the 21st century. There are currently several, most of them framed as enviro-activism and fuelled by what has been referred to as an increasingly glaring paradox: with increasing rights and revitalisation on the one hand and increasing threats towards the traditional Sámi settlement areas and professions on the other, in the form of mining, windmill parks and power plants. Two seminars in Tromsø during "Sámi week" 2019, discussed this paradox.

23 A United Nations Conference in Stockholm in 1972 has been described as the foundation of this shift (Hironaka 2014: 24).

24 For a more detailed discussion, see Johnson and Kraft (2018a, 2017).

25 I have not come across family metaphors or references to "elders" in material relating to the Alta-case.

26 Sara Marielle Gaup Beaska (1983-) is a critically acclaimed yoiker, known for her role in the band Adjágas and more recently in the band Arvvas. Sofia Jannok (1982-), from Sápmi on the Swedish side, is a widely known artist, singer and song-writer.

27 The Facebook post was later uploaded as a YouTube video, titled "Sámi Ceremony at Standing Rock".

28 This included a sewing course, centred on how to make skaller (gállohat in North Sámi), traditional Sámi shoes for usage in the winter.

29 See Varldens Sofia Jannok, a Swedish documentary series in three parts covering her life and career (www.svtplay.se/varldens-sofia-jannok).

30 Radio Isogaisa Episode 2, http://isogaisa.org/radio-isogaisa/. The episode is dedicated to Gaup and Beaska's visit to Standing Rock.

31 Interview with Kyrre Frank, Tromsø 28.08.18, and Morten Wolf Storeide, Finnskogen 8.09.18.

32 The event took place on 17th September 2016.

33 Solidarity events in Tromsø include a concert (organised by Synnøve Angell), various solidarity events in the town centre during fall 2016, filmed YouTube dedications, lectures and film-screenings. The Sámi professor of Law, Øyvind Ravna, gave several public lectures, based on a research stay in Midwestern United States and visits to Standing Rock. Many of the activists met again on 8th October 2018, for a screening of the Standing Rock documentary Eagle and Condor, with the Mohawk film-maker Paulette Moore present through Skype, thanking people for their support, answering questions, and sharing the idea behind the launch; that of a simultaneous screening across parts of the indigenous world, to celebrate what has among Native Americans become an Indigenous day-replacement of Columbus Day. I co-organised this event with Ellen Marie Jensen.

34 This included a section on indigenous peoples' rights within the context of social justice and environmental protection, and included Standing Rock activists, among them established leaders like Chief Arvol Looking Horse and two women who emerged as leaders during the the protests: HolyElk Lafferty and Donna Brave Bull Allard (NRK Sápmi, Larsen 2017a). See www.nobelpeaceprize.org/Nobel-Peace-Prize-Forum/2017-NobelPeace-Prize-Forum-Oslo (accessed November 2018).

35 Beaska and Jannok performed the yoik at the climate summit in Paris, 2015.

36 Tråante 2017 comprised of a one-week celebration marking the century that has passed since the first congress the Sámi people. Sara Marielle's yoik was presented on at least three occasions: the opening ceremony at the main square in Trondheim on 6th February (the Sámi national day), a seminar in the Methodist Church on that same day, and following the debate "From Alta via Fosen to Standing Rock" (Fra Alta via Fosen til Standing Rock).

37 www.facebook.com/Isogaisa-298385773536313/?fref $=$ nf (uploaded 14th November 2016. 533 views).

38 The camp was closed ahead of the winter season in 2017, and again in 2018, and is to be opened again during summer seasons as long as needed.

39 Seven hundred people gathered for a concert on a riverbank in Tana (a village of 500 people), on 25th July 2017. 
40 http://moratoriadoaimmahat.org/en/moratorium-office/

41 The friendships and networks established through this and other trips can and are being maintained. On returning from a one-month trip to Turtle Island on 17th May 2019, visiting Native American allies, including friends from Standing Rock, Beaska Niillas noted on his Facebook page: "A long journey this time and we learned a lot. Teachings that also will help us back in Sápmi. Found too many new relatives to tag all of you".

42 For instance, a poster featuring the Skábmagovat Film Festival (posted 16th November) connects Standing Rock and Ellos Deatnu, along with a statement of solidarity in English, Sámi and Finnish: "We stand in solidarity with Standing Rock and Ellos Deatnu! . . Ellos Deatnu! Mni Wiconi! Water is life!"

43 Posted 11 March 2017, https://youtube/HBObcQnncf8 (no longer available/accessible on this link).

44 Her greeting was made on receiving the honorary award of Spillemannsprisen, commonly regarded as the most important music prize in Norway.

45 A similar message was presented for the closure of the camp in 2018, along with expressions of gratefulness to the support of indigenous brothers and sisters, and solidarity with ongoing activism in Sápmi and beyond.

46 Scale is commonly defined in terms of relative size (small-large) and spatial reach (localglobal/private-public), see for instance Miller et al. (2016), Xiang (2013), and Lähdesmäki (2019). Scales can also be thought of in terms of spectra, as for instance from the highly private and intimate to the highly public and openly accessible, or in regard to value and authenticity (from good to bad religion, and false to authentic religion) (e.g. Miller et al 2016).

47 I first learnt of this through the Sámi newspaper Ságat, in a feature by the journalist Rita Heitman, titled "Ikke vindkraft på hellige fjell" (no wind-power on sacred mountains), (Ságat 5th April, 2019). Her Sámi informant was the reindeer herder and head of the local siida Thoralf Henriksen. The siida (home or community of reindeer herders) is called Leavvajoga ja Rásttigáisá sámesiida. For a follow-up in the newspaper Ságat, including an interview with Andreas Stångberg, in charge of cultural memories for the Sámi Parliament, see "Må prioritere konkrete saker" (must prioritise concrete cases), Sagat no. 68, 8th April 2019. For similar coverage referring explicitly to mountains in the area, see "Et hellig fjell og kinesere kan avgiøre ordførervalget" (A sacred mountain and the Chinese may decide the governor election (NRK Sápmi, www.nrk.no/sapmi/et-hellig-fjell-ogkinesere-kan-avgjore-ordforervalget-1.14698262), and "Kampen om reinens rike" (The struggle over the world of the reindeer), first published in Natur \& Miljo no.1, 2019, in digital version on 23.08.2019, by Tor Bjarne Christensen.

48 Solveig Joks, a researcher at Sámi Allaskuvla (Sámi University of Applied Sciences, in Kautokeino), published a letter to the editor of the regional newspaper Nordlys, on 26th February 2019 titled "Har regjeringen spurt Riehpovuotna/Repparfjorden og Gumppenjunni/Ulveryggen om lov?” (my translation: Has the government asked Riehpovuotna/ Repparfjorden and Gumppenjunni/Ulveryggen for permission?).

\section{References}

Alia, Valerie. 2010. The New Media Nation: Indigenous Peoples and Global Communication. New York and Oxford: Berghahn books.

Angell, Synnøve. 2009. Davvi Šuvva 1979 - Being Sámi: Becoming Indigenous: Vocal and Musical Manifestation of the Sámi and Indigenous Movement. Masters Thesis. SESAM, UiT. The Arctic University of Tromsø.

Bjerkli, Bjørn, and Per Selle. 2003. "Samisk offentlighet og makt". In Samer, makt og demokrati. Sametinget og den nye Samiske offentligheten. Makt og demokratiutredningen 1998-2003, edited by Bjørn Bjerkli and Per Selle. Oslo: Gyldendal Norsk Forlag, $15-47$. 
Clifford, James. 2013. Returns: Becoming Indigenous in the Twenty-First Century. Cambridge, MA: Harvard University Press.

Døving, Alexa, and Siv Ellen Kraft. 2013. Religion i Pressen. Oslo: Universitetsforlaget.

Eidheim, Harald. 1987. Aspects of the Lappish Minority Situation. Oslo Occasional Papers in Social Anthropology No. 14. Oslo: Department of Social Anthropology.

Eikjok, Jorunn. 2019. "Sultestreiken utenfor Stortinget i 1979 - min deltakelse". In Tana årbok. Deanu jahkegirji. Tana historielag, Deanu historjásearvi.

Felski, Rita and Susan Standford Friedman (eds.). 2013. Comparison: Theories, Approaches, Uses. Baltimore: The Johns Hopkins University Press.

Gordon, Linda. 2013. "A Meditation on Comparison in Historical Scholarship". In Comparison, Theories, Approaches, Uses, edited by Rita Felski and Susan Stanford Friedman. Baltimore: The Johns Hopkins University Press, 315-336.

Graff, Ola. 2016. Joikeforbudet i Kautokeino. Karasjok: Davvi Girji.

Guttormsen, Anders. 2000. "ČSV - ja mii daina oaivilduvvu”. Ottar 4: 24-26.

Hanna, P. Hille et al. 2016. "Conceptualizing Social Protest and the Significance of Protest Actions to Large Projects". The Extractive Industries and Society 3: 217-239.

Heger, Anders. 2016. "Amerikanernes kamp". Klassekampen 28: 10.

Heitmann, Kari. 1984. Altavaringene og Alta-saken. Sosial Identitet og Politisk Konflikt. Master-thesis. Institutt for sosialantropologi, Universitetet i Oslo.

Hironaka, Ann. 2014. Greening the Globe: World Society and Environmental Change.

Hjorthol, Lars Martin. 2006. Alta: Kraftkampen som utfordret statens makt. Oslo: Gyldendal.

Huarcaya, Sergio Miguel. 2015. "Performativity, Performance, and Indigenous Activism in Ecuador and the Andes". Comparative Studies in Society and History 57 (3): 806-837. DOI:10.1017/S0010417515000298

Jensen, Helge Hiram. 2015. State Transformation in the High North Cases of Environmental Justic Struggles. Ph.D dissertation. European University Institute, Florence.

Johansen, Anders, and Jens E. Kjeldsen. 2005. Virksomme Ord-Politiske taler 1814-2005. Oslo: Universitetsforlaget.

Johnson, Greg and Siv Ellen Kraft. 2017. "Introduction”. In Handbook of Indigenous Religion(s), edited by Greg Johnson and Siv Ellen Kraft. Leiden: Brill, 1-24.

Johnson, Greg and Siv Ellen Kraft. 2018a. "Standing Rock Religion(s): Ceremonies, Social Media, and Music Videos". Numen 65: 499-530. DOI:10.1163/15685276-12341510

Johnson, Greg and Siv Ellen Kraft. 2018b. "Protective Occupation, Emergent Networks, Rituals of Solidarity: Comparing Alta (Sápmi), Mauna Kea (Hawai'i), and Standing Rock (North Dakota)". In The Bloomsbury Handbook of Religion and Nature, edited by Laura Hobgood and Whitney Bauman. Bloomsbury Handbooks in Religion, Bloomsbury Academic, 185-198.

Keviselie. 1986. The First Nations. Indigenous Days'84, Algoalbmotbeaivvit'84, urbefolkningsdager' 84 , report, raporta, rapport. Tromsø: Keviselie forlag.

Kraft, Siv Ellen. 2016. "Kulturarvifisering av Ritualer. Sjamanisme i norsk Sápmi”. Chaos: Skandinavisk Tidsskrift for Religionshistoriske Studier 65: 53-74.

Lähdesmäki, Tuuli, Suzie Thomas, and Yujie Zhu. 2019. Politics of Scale: New Directions in Critical Heritage Studies. New York: Berghahn.

Larsen, Dan Robert. 2017a. "Standing Rock Kvinnene Takker Samene for All Hjelp og Støtte”. NRK Sápmi, published 4th October. www.nrk.no/sapmi/standing-rockkvinnene-takker-samene-for-all-hjelp-og-stotte-1.13718286, accessed November 2018.

Larsen, Tord. 2009. Den Globale Samtalen: Om Dialogens Muligheter. Oslo: Scandinavian Academic Press.

Larsson, Carl-Gøran. 2017. "DNB sa de solgte seg ut av "The Black Snake" - har fremdeles 7 milliarder i lån til oljerør-firmaene”. NRK Sápmi, published 8th November. 
www.nrk.no/ sapmi/dnb-sa-de-solgte-seg-ut-av-_the-black-snake_-_-har-likevel-7milliarder-i-lan-til-firmaene-bak-1.1374925

Manndal, Roger. 2011. "30 år siden okkupasjonen”, published 6th February. www.nrk. no/sapmi/30-ar-siden-okkupasjonen-1.7494956

Mikkelsen, Magnar. 1971. Masi, Norge. Oslo: Cappelen Forlag.

Mikkelsen, Magnar. 1980. Elva skal leve. Oslo: Cappelens forlag A.S.

Miller, Daniel et al. 2016. How the World Changed Social Media. London: UCL Press University College London.

Minde, Henry. 1982. "Trekk fra samenes historie i Alta". In Altaboka 1982: Årbok for Alta, edited by Alf Ragnar Nielssen et al. Alta historielag.

Minde, Henry. 2000. "Samesaken som ble en Urfolkssak". Ottar 4: 27-38.

Minde, Henry. 2003a. "Urfolksoffensiv, Folkerettsfokus og Styringskrise: Kampen for en ny Samepolitikk 1960-1990". In Samer, makt og demokrati. Sametinget og den nye Samiske Offentligheten. Makt og Demokratiutredningen 1998-2003, edited by Bjørn Bjerkli and Per Selle. Oslo: Gyldendal Norsk Forlag, 87-123.

Minde, Henry. 2003b. "The Challenge of Indigenism: The Struggle for Sami Rights in Norway 1960-1990”. In Indigenous Peoples: Resource Management and Global Rights, edited by Svein Jentoft, Henry Minde, and Ragnar Nilsen. Delft: Eburon Deltft, 75-106.

Minde, Henry. 2005. "The Alta Case: From the Local to the Global and Back Again”. In Discourses and Silences: Indigenous Peoples, Risks and Resistance, edited by Garth Cant, Anake Goodall, and Justine Inns. Christ Church: University of Canterbury, 13-34.

Niezen, Ronald. 2012. "Indigenous Religion and Human Rights". In Religion and Human Rights: An Introduction, edited by John Witte, Jr. and Christian M. Green. Oxford: Oxford University Press, 119-134.

Nilsen, Alfred. 2019. Altakampen: Miljøkampens Største Folkereisning. Tromsø: Haldde.

Parmann, George. 1980. Kampen om Alta - en Trussel mot vårt Demokrati? Oslo: Dreyers Publisher.

Pulk, Åse and Jenna Rasmus. 2016. "På tur til Nord-Dakota: Standing Rock-folket trenger all den støtten de kan få”. NRK Sápmi, published 20th September. www. nrk.no/sapmi/pa-tur-til-nord-dakota-standing-rock-folket-trenger-all-stotte-dekan-fa-1.13141906, accessed November 2018.

Selle, Per, Anne Julie Semb, Kristin Strømsnes, and Åsta Dyrnes Nordø. 2015. Den Samiske Medborgeren. Oslo: Cappelen Damm.

Simpson, Audra. 2014. Mohawk Interruptus: Political Life across the Borders of Settler States. Durham and London: Duke University Press.

Solbakk, John T. 2010. Álttà-Guovdageaineanu Stuimmi Birra. Dráma odda áiggis. Drama i Nyere tid. Kampen om Alta-Kautokeinoelva. Karasjok: CálliidLágádus - Forfatternes Forlag, stiftelse.

Somby, Ánde. 1999. "A Story about how Another Hydroelectric Dam-Project Was Forced through in Norway". Indigenous Affairs 3-4.

Sundström, Olle. 2016. "Reconstructing Religious Identity among the Sámi of Scandinavia: Christian Sámi, Contextual Theology in the Twenty-First Century”. Senri Ethnological Studies 93: 211-228.

Thuen, Trond. 1980. "Innledning". In Samene - Urbefolkning og Minoritet, edited by Trond Thuen. Tromsø, Oslo, Bergen: Universitetsforlaget, 9-21.

Turner, Victor. 1974. "Liminal to Liminoid, in Play, Flow, and Ritual: An Essay in Comparative Symbology". Rice Institute Pamphlet: Rice University Studies 60 (3). Rice University. http://hdl.handle.net/1911/63159

Valkeapää, Nils-Aslak. 1983. Greetings from Lappland: The Sámi, Europe's forgotten People. London: Zed Press. 
Valkeapää, Nils-Aslak. 1988. Beaivi, áhčázan. Norge: DAT (translated into Norwegian as Solen, min Far in 1990).

Vassvik, Tuula Sharma. 2019. Standing Rock as a Place of Learning: Strengthening Indigenous Identities. Masters thesis in indigenous studies. SESAM, UiT The Arctic University of Norway.

Verstad, Anders Boine and Ksenia Novikova. 2017. " Samisk musikkikon engasjerer seg i 'laksestriden' rundt Tana-elva”. NRK, published 17th July. www.nrk.no/finnmark/ Samisk-musikkikon-engasjerer-seg-i-_laksestriden_-rundt-tanaelva-1.13606049, accessed November.

Xiang, Biao. 2013. "Multi-Scalar Ethnography: An Approach for Critical Engagement with Migration and Social Change". Ethnography 14 (3): 282-299. 